\title{
Assessing the Suitability of Bromilow Time-Cost (BTC) Model to Predict Project Time on Road Construction Projects in Botswana
}

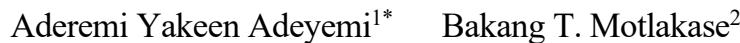 \\ 1.Department of Construction Engineering, Gaborone University College, Gaborone, Botswana \\ 2.Elsamex Transportation-ITNL JVCA, Kanye, Botswana
}

\begin{abstract}
The construction industry researchers have still found the Bromilow Time-Cost performance model given by $\mathrm{T}=$ $\mathrm{KC}^{\mathrm{B}}$ very relevant to today's construction processes. The only aspects that change in the model are the coefficient of the equation $\mathrm{K}$, and the power of the cost $\mathrm{B}$. This suggests that the equation characteristics only change with the type of project and the environment in which the project was executed. The model helps to forecast the duration of a project using the estimated final cost of the project. A fast estimate of construction time in the early phase of a project helps the contractor in avoiding time and cost overruns that might lead to dispute and possibly litigation. The motivation for this research was derived from the above assertions. Data for formulating the Bromilow model for road construction projects were collected from a sample of $\mathbf{5 4}$ road projects executed by the Botswana Department of Roads. Analysis showed that the Bromilow time-cost performance model for road construction project in Botswana is given by:

$\mathrm{T}=14.11116 \mathrm{C}^{0.155488}$

With $\mathrm{R}^{2}=0.283266$ and adjusted $\mathrm{R}^{2}=0.269483$. Even though the $\mathrm{R}^{2}$ and the adjusted $\mathrm{R}^{2}$ were considered a good fit for the data and the $\mathrm{R}^{2}$ was within the range of what was found in the previous studies around the world which is between 0.205 and 0.850 , the model may not provide a good base in Botswana for estimating the duration of a project at the early life when the early cost is known. It is recommended that data on recently completed projects be provided for in-depth analysis of the influence of variables such as funding, payment, rework, change orders , and many other agents of time-overruns might have contributed to project time in the Botswana construction industry.
\end{abstract}

Keywords: suitability, Bromilow's model, project time, road construction projects, Botswana

DOI: $10.7176 / \mathrm{CER} / 12-12-04$

Publication date: December $31^{\text {st }} 2020$

\section{Introduction}

In general, the Botswana construction sectors can be roughly categorized into real estate (housing. industrial parks. plants, office, malls, hotels) and infrastructure comprising roads, rail, bridges, airports, hospitals, schools, and universities (Gorgenlander, 2011). The sector strives for steady growth on account of urbanization, economic development and people's rising need for improved quality of living. The construction industry is a complex environment in which each organization is faced with numerous opportunities and threats (Walker, 1995). Higher construction costs have been the concern on projects undertaken for the government of Botswana over a period of time. The majority of the projects that have been delivered were either delayed in terms of completion time or exceeded the budgeted project amount. This has an effect on the development budget for government and leads to reallocation of the scare financial resources to projects that have exceeded their budgeted amounts. It is therefore important to identify the main dominating factors leading to high construction costs so that efforts can be put in place on these factors in order to reduce construction costs in Botswana.

The aim of the study was to find out the factors contributing to construction cost in Botswana and the associated objectives were to: (i) identify the main factors affecting construction costs in Botswana; (ii) determine the severity rank of each cost factors; (iii) suggest solutions that could minimize construction costs in Botswana.

\section{The Construction Industry in Botswana}

The construction industry in Botswana is an important sector of the economy contributing about 5.3\% to the GDP (Adeyemi and Masalila, 2016); and the third largest employer of labour after Mining and Agriculture industries. The major client of the industry is government. Despite its importance in the socio-economic growth of Botswana, the industry is bedeviled with project failures manifesting as time and cost overruns across projects. Chimwaso (2000) in his research concluded that $70 \%$ of Botswana projects do incur time and cost overruns. Ever since this research output, there has been strings of headlines reporting project failure in the country with many blamed on irrevocable use of low-bid system and very slow application of best value procurement.

The major financier of road construction projects in Botswana in the Botswana Government through the Ministry of Works and Transport represented by the Department of Roads. A number of foreign funding agencies have been involved in road project, studies and technical assistance. Contributions have been received from AA, ADB, ADF, BADEA, CIDA, DANIDA, EEC, EDF, IBRD, IDA, Kwf, Kuwait, NORAD, ODA, OPEC, UNCDF 
and USAID and some of the projects that are externally funded are still ongoing. The Botswana Roads Department uses competitive tendering as well as selective bidding for some other specialist mega projects. The criteria for selection of contractors as specified in the tender documents for construction include the following:

- Competence and integrity

- $\quad$ Past performance of the contractor and its reputation in terms of similar jobs (track record)

- The personnel strength of the contractor, its financial status and its ability to co-finance projects.

- The contractor's scheduled time of completion and final tender price.

The contractual arrangement is as shown on Figure 1 below. The client first appoints the consulting Engineers to advice and design on a variety of specialist works, e.g. structural, civil works and pavement design. Consultants are also engaged to provide a site team during construction to ensure that the project is kept within cost and complies with the design. The principal contractor is employed by the client on the advice of the engineer by nomination or competitive tendering. They are required to administer the construction programme within the Engineer's direction. A domestic subcontractor is employed by the principal contractor to assist with the general construction or installation, e.g. bricklaying, fencing, etc.

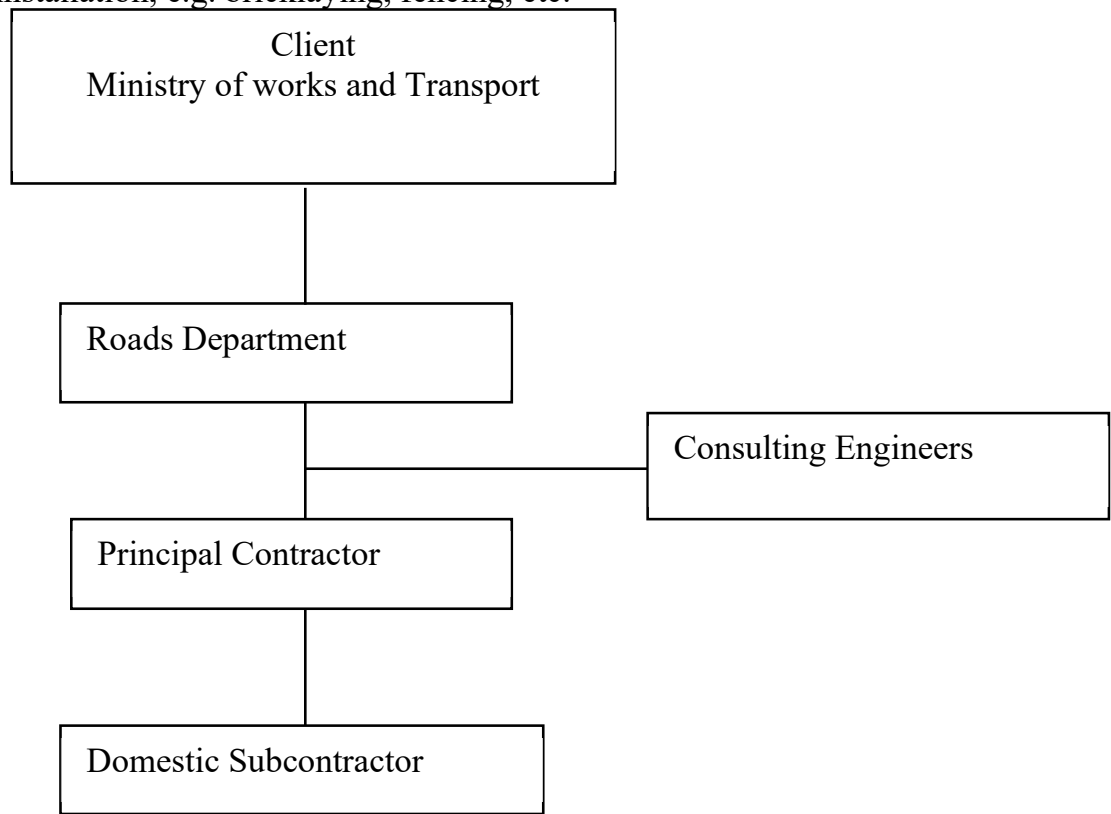

Figure1: Contractual Arrangement in the Construction of Roads in Botswana

Source Adeyemi and Segwabe (2016)

The relative high resource commitment by the government of Botswana to the construction of road projects has been highlighted in the Department of Roads website, (www.roads.gov.bw); during the years 1966 to 1986 more than P260 million has been invested in new road infrastructure. During the National Development Plan (NDP) 7, for the period from 1991 to 1997 P870 746559.00 was spent for the development of the network. During the National Development Plan 8, for the period from 1997 to 2003 P2 661274384.00 was spent. For the period from 2003 to 2009 the estimated amount was P2467 660000.00.

Despite government sincere efforts to provide adequate road infrastructure for the country, the proposition is often stalled by the low-bid-system with its associated corrupt system. For example, Adeyemi and Segwabe (2016) stated that out of the 31 road construction projects that were completed between 1996 to 2005 by the Department of Roads, only $6.5 \%$ of the projects were completed within the scheduled completion dates and $32 \%$ were completed within budget. These indicate that there are serious problems within the construction industry in Botswana most especially on road project delivery. Adding to this is the inadequacy of cost prediction at the early stage of the project. This is where Bromilow Time Cost (BTC) is useful.

\section{Methodology}

This research made use of purely secondary data collected from the archival documents of the Department of Roads, Gaborone, Botswana. The data consists of initial contract cost of each project and the actual cost on one hand, and the initial contract duration and the corresponding actual duration on the other. A total of 54 projects whose details were complete were included in the analysis. All the projects were executed between the years 1997 and 2010. Bromilow time-cost model (Equation 1) was used to quantitatively provide the construction time on 54 Roads Department projects. construction projects (Table 1) using the least square regression analysis. The constant $\mathrm{K}$ and $\mathrm{B}$ were calculated through the use of Statistical Package for Social Science (SPSS). 
Table 1. Time and Cost Performance of Roads Department Projects

\begin{tabular}{|c|c|c|c|c|c|c|c|c|c|}
\hline S/No & $\begin{array}{l}\text { Initial } \\
\text { Duration } \\
\text { (Months) }\end{array}$ & $\begin{array}{l}\text { Actual } \\
\text { Duration } \\
\text { (Months) }\end{array}$ & $\begin{array}{l}\text { Initial } \\
\text { Cost } \\
\text { (Million } \\
\text { BWP*) }\end{array}$ & $\begin{array}{l}\text { Actual } \\
\text { Cost } \\
\text { (Million } \\
\text { BWP*) }\end{array}$ & S/No & $\begin{array}{l}\text { Initial } \\
\text { Duration } \\
\text { Months) }\end{array}$ & $\begin{array}{l}\text { Actual } \\
\text { Duration } \\
\text { (Months) }\end{array}$ & $\begin{array}{l}\text { Initial } \\
\text { Cost } \\
\text { (Million } \\
\text { BWP*) }\end{array}$ & $\begin{array}{l}\text { Actual } \\
\text { Cost } \\
\text { (Million } \\
\text { BWP*) }\end{array}$ \\
\hline 1 & 11 & 24 & 12.194 & 13.6 & 28 & 20 & 27 & 54.24 & 69.63 \\
\hline 2 & 18 & 28 & 59.02 & 61.859 & 29 & 24 & 33 & 151.446 & 143.203 \\
\hline 3 & 12 & 8 & 78.558 & 78.558 & 30 & 9 & 15 & 4.394 & 3.85 \\
\hline 4 & 15 & 19 & 49.9 & 63.7 & 31 & 13 & 16 & 12.506 & 10.113 \\
\hline 5 & 18 & 23 & 58.9 & 65.262 & 32 & 20 & 28 & 57.5 & 75 \\
\hline 6 & 22 & 20 & 98 & 102.99 & 33 & 8 & 10 & 3.8 & 4.047 \\
\hline 7 & 10 & 17 & 25.2 & 27 & 34 & 20 & 35 & 99.4 & 102.957 \\
\hline 8 & 16 & 18 & 17.87 & 18.829 & 35 & 20 & 26 & 98.1 & 104 \\
\hline 9 & 18 & 26 & 45.7 & 47.44 & 36 & 17 & 24 & 89.39 & 94.513 \\
\hline 10 & 17 & 19 & 21.3 & 25.122 & 37 & 8 & 16 & 4.94 & 4.94 \\
\hline 11 & 15 & 19 & 13.565 & 13.503 & 38 & 6.7 & 7 & 6.88 & 6.785 \\
\hline 12 & 13 & 28 & 6.844 & 6.864 & 39 & 13 & 11 & 17.028 & 14.424 \\
\hline 13 & 12.5 & 31 & 7.633 & 8.594 & 40 & 20 & 39 & 59.87 & 75.023 \\
\hline 14 & 12.5 & 20 & 8.98 & 9.877 & 41 & 20 & 26 & 40.49 & 53.3 \\
\hline 15 & 24 & 26 & 31.9 & 48.349 & 42 & 16 & 18 & 41.187 & 47.155 \\
\hline 16 & 19 & 24 & 61.9 & 71.02 & 43 & 10 & 16 & 5.411 & 5.164 \\
\hline 17 & 24 & 27 & 85.6 & 108.266 & 44 & 10 & 15 & 6.067 & 5.311 \\
\hline 18 & 14 & 15 & 16.82 & 16.155 & 45 & 12 & 18 & 12.992 & 13.659 \\
\hline 19 & 12 & 46 & 8.09 & 7.571 & 46 & 24 & 27 & 386 & 415 \\
\hline 20 & 14 & 15 & 10.45 & 10.245 & 47 & 24 & 27 & 272 & 332 \\
\hline 21 & 12 & 15 & 4.91 & 6.031 & 48 & 30 & 44 & 536 & 400 \\
\hline 22 & 14 & 37 & 11.42 & 12.745 & 49 & 30 & 51 & 381.6 & 438.8 \\
\hline 23 & 13 & 38 & 3.31 & 4.164 & 50 & 24 & 41 & 400 & 609 \\
\hline 24 & 13 & 32 & 3.542 & 5.567 & 51 & 18 & 28 & 186 & 198 \\
\hline 25 & 18 & 33 & 44.3 & 54.756 & 52 & 12 & 14 & 23.46 & 24.46 \\
\hline 26 & 12 & 24 & 9.711 & 8.134 & 53 & 30 & 48 & 200.7 & 228.7 \\
\hline 27 & 12 & 18 & 5.86 & 5.236 & 54 & 30 & 34 & 146.655 & 160.269 \\
\hline
\end{tabular}

*10 BWP (Botswana Pula) $\approx 1$ USD

\section{Analyses of Results and Discussion}

Table 2 shows the SPSS details for calculating K and B for the 54 projects studied. Convergence for the least square process was achieved after six iterations.

Table 2: Calculated constants $\mathrm{K}$ and $\mathrm{B}$ using the least square method

\begin{tabular}{|l|l|l|l|l||}
\hline \multicolumn{2}{|l|}{ Coefficient } & Std. Error & t-Statistic & Probability \\
\hline \hline K & 14.11116 & 2.023719 & 6.972887 & 0.0000 \\
\hline \hline $\mathrm{T}=14.11116 \mathrm{C}^{0.155488}$ & 0.155488 & 0.032940 & 4.720341 & 0.0000 \\
\hline \hline R-squared & 0.283266 & Mean dependent variable & 24.88889 \\
\hline Adjusted R-squared & 0.269483 & S.D dependent variable & 10.22883 \\
\hline S.E of regression & 8.742611 & Akaike info criterion & 7.210629 \\
\hline Sum squared residual & 3974.529 & Schwarz criterion & 7.284295 \\
\hline Log likelihood & -192.6870 & Hannan-Quinn criteria & 7.239039 \\
\hline Durbin-Watson stat & 1.534876 & & \\
\hline
\end{tabular}

$\mathrm{R}$-squared is a statistical measure in percentage of the variability of the response data around its mean. R-squared is always between 0 and $100 \%$ where:

- $0 \%$ indicates that the model explains none of the variability of the response data around its mean.

- $100 \%$ indicates that the model explains all the variability of the response data around its mean. In general, the higher the R-squared, the better the model fits the data.

From Table 2, the Bromilow time-cost relationship for the 54 roads projects is as given in equation 2.

$\mathrm{T}=\mathbf{1 4 . 1 1 1 1 C}^{\mathbf{0 . 1 5 5 5}}$

Comparative results of similar studies around the world are as presented in Table 3. 
Table 3: Bromilow's Time-Cost Model for Some Studies Around the World

\begin{tabular}{|c|c|c|}
\hline Researcher(s) & Country of Research & Equation \\
\hline Bromilow (1969) & Australia & $\begin{array}{l}\mathrm{T}=211 \mathrm{C}^{0.3} \text { (Public) } \\
\mathrm{T}=156 \mathrm{C}^{0.3} \text { (Private) }\end{array}$ \\
\hline Bromilow (1974) & Australia & $\mathrm{T}=313 \mathrm{C}^{0.3}$ \\
\hline Chan (1991) & Hong Kong & $\mathrm{T}=152 \mathrm{C}^{0.29}$ (Unknown) \\
\hline Kaka and Price (1991) & United Kingdom & $\begin{array}{l}\mathrm{T}=398 \mathrm{C}^{0.32} \text { (Public) } \\
\mathrm{T}=274 \mathrm{C}^{0.21} \text { (Private) }\end{array}$ \\
\hline $\begin{array}{l}\text { Yeong (1994) } \\
\text { Yeong (1994) }\end{array}$ & $\begin{array}{l}\text { Australia } \\
\text { Malaysia }\end{array}$ & $\begin{array}{l}\mathrm{T}=287 \mathrm{C}^{0237} \text { (Public) } \\
\mathrm{T}=161 \mathrm{C}^{0.367} \text { (Private) } \\
\mathrm{T}=269 \mathrm{C}^{0: 215} \text { (public and Private) } \\
\mathrm{T}=518 \mathrm{C}^{0.352} \text { (Public) }\end{array}$ \\
\hline Kumaraswamy and Chan (1995) & $\begin{array}{l}\text { Hong Kong } \\
\text { United Kingdom }\end{array}$ & $\begin{array}{l}\mathrm{T}=216.3 \mathrm{C}^{0.253} \text { Public) } \\
\mathrm{T}=250 \mathrm{C}^{0.215} \text { (Private) } \\
\mathrm{T}=486.7 \mathrm{C}^{0.205} \text { (Public) }\end{array}$ \\
\hline Mak et al. (2000) & Australia & $\mathrm{T}=131 \mathrm{C}^{0.131}$ (All types of project) \\
\hline Ng et al. (2001) & Australia & $\mathrm{T}=130 \mathrm{C}^{0.310}$ (Public \& private) \\
\hline Chan (2001) & Malaysia & $\mathrm{T}=269 \mathrm{C}^{0.315}$ (Public) \\
\hline Choudhry et al. (2002) & Bangladesh & $\mathrm{T}=149 \mathrm{C}^{0.27}$ (Private) \\
\hline Endut et al. (2006) & Malaysia & $\mathrm{T}=303 \mathrm{C}^{0.157(\text { Public) }}$ \\
\hline Ogunsemi and Jagboro (2006) & Nigeria & $\mathrm{T}=69 \mathrm{C}^{0.255}$ (Public) \\
\hline Hoffman et al. (2007) & USA & $\mathrm{T}=26.8 \mathrm{C}^{0.202}$ \\
\hline Zujo and Car-Pusic (2008) & Bosnia and Herzegovina. & $\mathrm{T}=79 \mathrm{C}^{0.41}$ (Public) \\
\hline Car-Pusic and Miladen (2009) & $\begin{array}{l}\text { Croatia } \\
\text { Bosnia Herzegovina }\end{array}$ & $\begin{array}{l}\mathrm{T}=88 \mathrm{C}^{0.54} \\
\mathrm{~T}=70 \mathrm{C}^{0.52} \text { (New Construction) }\end{array}$ \\
\hline Le- Hoai et al. (2009) & $\begin{array}{l}\text { Vietnam } \\
\text { South Korea }\end{array}$ & $\begin{array}{l}\mathrm{T}=94 \mathrm{C}^{0.338} \\
\mathrm{~T}=341 \mathrm{C}^{0.175}\end{array}$ \\
\hline Ameyaw et al. (2012) & Ghana & $\mathrm{T}=3.17 \mathrm{C}^{0.378}$ (Public) \\
\hline Rahman et al. (2014) & Bangladesh & $\mathrm{T}=156 \mathrm{C}^{0.36}$ (Private) \\
\hline Mačková and Baskova (2014) & Slovakia & $\mathrm{T}=384 \mathrm{C}^{0.263}$ (Private) \\
\hline Adeyemi and Masalila (2016) & Botswana & $\begin{array}{l}\mathrm{T}=01.18 \mathrm{C}^{0.362} \\
\text { (Gaborone City Council) }\end{array}$ \\
\hline Adeyemi and Motlakase (2020) & Botswana & 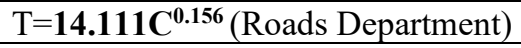 \\
\hline
\end{tabular}

In this study, R-Square is 0.283266 . Even though the $\mathrm{R}^{2}$ compares favourably with what is found in literature that R-squared is usually between 0.205 to 0.850 when BTC are compared among countries (Rahman et al. 2014), this value is rather weak to predict the project time $(\mathrm{T})$.

\section{Conclusion}

Data reflecting duration and cost of 54 road construction projects in Botswana were used to construct a Bromilow time- cost model. The model was $\mathrm{T}=14.111 \mathrm{C}^{0.156}$ with $\mathrm{R}^{2}=0.283266$ and adjusted $\mathrm{R}^{2}=0.269483$. The $\mathrm{R}^{2}$ and adjusted $\mathrm{R}^{2}$ were considered a good fit for the data and the $\mathrm{R}^{2}$ was within the range of what was found in the previous studies around the world which is between 0.205 and 0.850 . However, this model may not provide a good base in Botswana for estimating the duration of a project at the early life when the early cost is known. It is recommended that data on recently completed projects be provided for in-depth analysis of the influence of cost variables (Adeyemi and Nduna,2019) might have affected project time in the Botswana construction industry

\section{References}

Adeyemi, A. Y. and Nduna, K. (2019). Factors Contributing to Construction Costs in Botswana - Perspective from Construction Contractors. Civil and Environmental Research, Vol. 11, No 12.

Adeyemi, A. Y. and Motlakase, B. T. (2017). Time-Cost Performance of Road Construction Projects in Botswana. Proceedings of the $4^{\text {th }}$ International on Transportation in Africa (ICTA 2017), Abuja, Nigeria, $11^{\text {th }}$ to $13^{\text {th }}$ October, pp 76-84.

Adeyemi, A. Y. and Segwabe, O. (2016). Rank-Order Analysis of Factors Causing Claims on Road Construction Projects in Botswana. Journal of the Advancement of Performance Information and Value (JAPIV). 8(2), pp.58-77.

Adeyemi, A. Y. and Masalila, K. (2016). Delay Factors and Time-Cost Performance of Construction Projects in Gaborone City Council, Botswana. Journal for the Advancement of Performance Information \& Value 
(JAPIV), 8 (10), pp. 4-1 to 4-18.

Akiner, I. and Akiner M. E. (2009). Evaluation of Turkish Construction Industry through the Challenges and Globalization. Organization, Technology and Management in Construction: An International Journal, 1(2), 64-71.

Ameyaw, C., Mensah S. and Arthur, Y. D. (2012). Applicability of Bromilow's Time-Cost

Model on Building Projects in Ghana. In: Proceedings, $4^{\text {th }}$ West Africa Built Environment

Research (WABER), Conference, Abuja, Nigeria, 881-888.

Anaman, K. A., Osei-Amposah, C. (2007). Analysis of the Causality links between the Growth of the

Construction Industry and the Growth of the Macro-Economy in Ghana. Construction Management and

Economics 25 (9), 951-961.

Bon, R. (1992). The World Construction Market170-85, In: Building Economics and Construction Management. Proceedings of the CIB W65 Symposium, Sydney.

Bon, R. (1992). The future of International Construction: Secular Patters of Growth and Decline, Habitat International, 16(3), 119.

Bromilow, F.J. (1969). Contract Time Performance Expectations and the reality. Building Forum 1(3), 70-80.

Bromilow, F. J. (1974). Measurement and Scheduling of Construction Time and Cost Performance in Building Industry. The Chartered Builder, 10, 79-82.

Car- Pusic, D. and Miladen, R. (2009). Construction Time Model in Croatia, Engineering Modeling 1-4, 63-70.

Chan, A.P.C (2001) Time-cost relationship of public sector projects in Malaysia. International journal of Project Management 19, 223-229

Chimwaso, D. K. (2000). An Evaluation of Cost Performance of Public Projects: Case of

Botswana. Available at: https://www.researchgate.net/publication/237275526. Visited on July 16, 2017.

Choudhury, I.; Khan, M. and Matin, A. (2002). Relationship between Construction Time and Project Cost of Health Sector Construction Works in Bangladesh. In: ASC Proceedings of the 38th Annual Conference, Virginia Polytechnic Institute and State University - Blacksburg, Virginia, April 11 - 13, pp 337 -342.

Choudhury, I.; Rajan, S. S. (2003). Time-Cost Relationship for residential construction in Texas. In: Proceedings of the $20^{\text {th }}$ International Conference on Information Technology in Construction, Auckland, New Zealand.

Farooqui, R. U.; Ahmed, S. M. and Lodi, S. H. (2008). Assessment of Pakistani Construction Industry- Current Performance and the Way Forward, Journal for the Advancement of Performance Information and Value Voll (1), pp. 51-72.

Endut, I.R.; Akinloye, A.; Kelly, J. (2006) Relationship between duration and cost of Malaysian construction projects. Proceedings of the International Conference in the Built Environment in the 21st Century, pp. 299309

Giang, D. T. H. and Pheng L. S. (2011). Role of Construction in Economic Development: Review of Key Concepts in the Past 40 Years, Habitat International 35, 118-135.

Hillebrandt, P. M. (2000) Economic Theory and the Construction Industry. Third Edition. London: Macmillan Press Ltd.

Hoffman, G. J.; Thal, A. E.; Webb, T. S.; Weir, J. D. (2007). Estimating Performance Time for Construction Projects. Journal of Management in Engineering (ASCE), 23(4), 193-199.

Jiang, Q. (2013). Analysis on the Relationship between GDP and Construction Based on the Data of UK and China. In: Proceeding of the International Conference on Education Technology and Management Science (ICETMS), 1296-1299.

Kaka, A. and Price, A. D. F. (1991). Relationship between Value and Duration of Construction Projects. Construction Management and Economics, 9, 383-400.

Khan, M. and Matin, A. (2002). Relationship between Construction Time and Project Cost of Health Sector Construction Works in Bangladesh, In: ASCE Proceedings of the $38^{\text {th }}$ annual conference, Virginia Polytechnic and State Institute, Blacksburg, Virginia, pp.337-342, 11-13 April.

Kumaraswamy, M. M. and Chan, D. W. M. (1995). Determinants of Construction Duration. Construction Management and Economics, 13, 209-217.

Le-Hoai, L.; Lee, Y. D. and Cho, J. W. (2009), Construction of Time-Cost Model for Building Projects in Vietnam. Korean Journal of Construction Engineering and Management (KJCEM), 10(3), pp.130-138.

Lopes, J. Nunes, A. and Balsa, C. (2011). The Long-run Relationship between the and the national economy in Cape Verde. International Journal of Strategic Property Management Construction Sector 15(1), 48-59.

Lopes, J. Ruddock L. and Ribeiro, F. L. (2002). Investment in Construction and Economic Growth in Developing Countries, Building Research and Information, 30(3), pp.152-159.

Mačková, D. and Baskova R. (2014). Applicability of Bromilow's Time-Cost Model for Residential Projects in Slovakia. Journal of Civil Engineering, Vol. 9(2), pp. 5-12.

Mak, M.Y., Ng, S. T., Chen, S. E.and Varnam, M. (2000). The Relationship between Economic

Indicators and Bromilow's Time-Cost Model: a Pilot Study, In: Akintoye, A. (Ed.), Proceedings 
of the $16^{\text {th }}$ Annual ARCOM Conference, Glasgow Caledonian University, 2, 587-595.

Mavridis, S. C. and Vatalis, K. I. (2015). Investment in Construction and Economic Growth in Greece. Procedia Economics and Finance, 24, 386-394.

Ng, S.T.; Mak, M.M.Y.; Skitmore, R.M.; Lam, K.C.; Varnam, M. (2001) The predictive ability of Bromilow's time-cost model. Construction management and Economics 19:2, 165-173

Ofori, G. (1980). The Construction Industries of the Developing Countries. The Case of Ghana, University College, London.

Ofori, G. (1990). The Construction Industry: Aspects of Its Economic and Management, Singapore University Press.

Ogunsemi, D. R. (2006). Time-cost Model for Building Projects in Nigeria. Construction

Management and Economics, 24(3), 253-258.

Ozkan, F., Ozkan O. and Gunduz, M. (2012). Causal Relationship between Construction Investment Policy and Economic Growth in Turkey. Technological Forecasting and Social Change, 79, pp.362-370.

Rahman, M.D.; Mizanur, L. Y. D.; Ha, D. K. and Chun, Y.H. (2014). Development of Time-Cost Models for Building construction projects in Bangladesh, KICEM Journal of Construction Engineering and Project Management, Vol. 4(3), pp. 13-20.

Tan, W. (2002). Construction and Economic Development in Selected LDCs: Past, Present and Future. Construction Management and Economics, 20(7), 593-599.

Turin, D. A. (1973). The Construction Industry: Its Economic Significance and Its Role in Development, UCERG, London.

Turin, D. A. (1978). Construction and Development. Habitat International, Vol.3, No1 and 2, 33-45.

Wells J.(1987) The Construction Industry in Developing Countries: Alternative Strategies for Development, Croom Helm Ltd. London.

World Bank (1984). The Construction Industry: Issues and Strategies in Developing Countries, International Bank for Reconstruction and Development, The World Bank, Washington D. C.

Yeong, C. M. (1994), Time and Cost Performance of Building Contracts in Australia and Malaysia, MSc Thesis, University of South Australia, Adelaide, Australia.

Zujo, V. and Car-Pusic, D. (2008). Application of Time-Cost Model in Construction Project Management, In: Proceedings, Organization, Technology and Management in Construction $8^{\text {th }}$ Conference, 17-20

September, Umag, Croatia. Available at: https://bib.irb.hr/datoteka/444400.92-ujo-Car-Pui.pdf, Visited 16/07/2017.

$\begin{array}{ll}\text { Appendix } & \\ \text { List of Abbreviations } \\ \text { ADB } & \text { African Development Bank. } \\ \text { BADEA } & \text { Arab Bank for Economic Development in Africa } \\ \text { CIDA } & \text { Canadian International Development Agency } \\ \text { DANIDA } & \text { Danish International Development Agency } \\ \text { EEC } & \text { European Economic Community } \\ \text { IBRD } & \text { International Bank for reconstruction and Development } \\ \text { NORAD } & \text { North American Aerospace Defense Command } \\ \text { OPEC } & \text { Organization of Petroleum Exporting Countries } \\ \text { UNCDF } & \text { United Nations Capital Development Fund } \\ \text { USAID } & \text { United States Agency for International Development }\end{array}$

